\title{
Endophytic fungi from Amomum siamense
}

\author{
Boonsom Bussaban, Saisamorn Lumyong, Pipob Lumyong, Eric H.C. McKenzie, \\ and Kevin D. Hyde
}

\begin{abstract}
Endophytic fungi were isolated from apparently healthy organs of the wild ginger Amomum siamense Criab., including leaves, pseudostems, and rhizomes, collected from two sites in Doi Suthep-Pui National Park, Thailand. Endophytes were relatively common with an isolate prevalence of $70 \%-83 \%$ at the two sites sampled in the wet and dry seasons. The endophyte assemblages from the two sites were diverse and comprised 7 Ascomycetes and 26 mitosporic fungi. Colletotrichum "gloeosporioides" (Penz.) Penz. \& Sacc. in Penz., Glomerella spp., xylariaceous fungi, and Phomopsis spp. were consistently dominant as endophytes on Amomum siamense, but many rare species and mycelia sterilia were also recorded. There was no significant difference between the number of isolates recovered from leaves containing vein tissues and those containing intervein tissues, independent of leaf age. Most taxa showed a preference for either leaf tissue or pseudostems. Two new Ascomycetes species, Gaeumannomyces amomi and Leiosphaerella amomi, were discovered from leaves and rhizomes, respectively, and four species of Pyricularia, including three new species, were isolated from leaves.
\end{abstract}

Key words: Zingiberaceae endophytes, isolate prevalence, tissue specificity, seasonal effects.

Résumé : Des champignons endophytes ont été isolés d'organes apparemment sains du gingembre sauvage Amomum siamense Criab., soit à partir des feuilles, des pseudotiges et des rhizomes récoltés dans deux sites du Parc National Doi Suthep-Pui en Thailande. Ces endophytes étaient relativement communs, car leur prévalence d'isolement était de $70 \%-83 \%$ aux deux endroits échantillonnés et ce en saisons sèches ou humides. Les populations d'endophytes de chacun des sites étaient diversifiées et comprenaient 7 Ascomycètes et 26 champignons à reproduction asexuée. Chez l'Amomum siamense, les endophytes régulièrement dominants étaient Colletotrichum "gloeosporioides" (Penz.) Penz. \& Sacc. in Penz., Glomerella spp., des champignons du groupe des Xylariaceae et Phomopsis spp. mais plusieurs espèces rares ainsi que des mycéliums stériles ont aussi été observés. Il n’y avait pas de différence significative dans le nombre d'isolats provenant de feuilles contenant du tissu veineux ou intraveineux, indépendemment de l'âge de la feuille. La majorité des taxa ont montré une préférence pour le feuillage ou les pseudotiges. Deux nouvelles espèces

d'Ascomycètes, Gaeumannomyces amomi et Leiosphaerella amomi, ont été découvertes respectivement dans les feuilles et les rhizomes et quatre espèces de Pyricularia, incluant trois nouvelles espèces, ont été isolées à partir des feuilles.

Mots clés : Zingiberaceae endophytes, prévalence des isolats, spécificité tissulaire, effets saisonniers.

[Traduit par la Rédaction]

\section{Introduction}

Most reports of endophytes from monocotyledonous plants have concentrated on temperate grasses, with an emphasis on clavicipitaceous endophytes and their beneficial

Received February 28, 2001. Revision received August 8, 2001. Accepted August 16, 2001. Published on the NRC Research Press Web site at http://cjm.nrc.ca on October 12, 2001.

B. Bussaban and S. Lumyong. ${ }^{1}$ Department of Biology, Faculty of Science, Chiang Mai University, Chiang Mai 50200 , Thailand.

P. Lumyong. Department of Plant Pathology, Faculty of Agriculture, Chiang Mai University, Chiang Mai 50200, Thailand.

E.H.C. McKenzie. Herbarium PDD, Landcare Research, Private Bag 92170, Auckland, New Zealand.

K.D. Hyde. Centre for Research in Fungal Diversity, Department of Ecology and Biodiversity, The University of Hong Kong, Pokfulam Road, Hong Kong.

${ }^{1}$ Corresponding author (e-mail: scboi009@ chiangmai.ac.th). role to the host (Clay 1986; Dahlman et al. 1991). In the tropics, comprehensive studies on endophytes in palms have been carried out by Rodrigues and Samuels (1990); Rodrigues (1994); Taylor et al. (1999); and Fröhlich et al. (2000), while Umali et al. (1999) and Lumyong et al. (2000) have investigated the endophytic fungi in leaves, nodes, and internodes of bamboo. These studies have shown the effects of factors, such as leaf age, leaf tissue type, stage of plant growth, site, altitude, and seasonality, on endophyte assemblages and colonization. Brown et al. (1998) investigated the endophytes in banana leaves, discussing their potential in biological control.

Saprobic and pathogenic fungi associated with Zingiberaceae (ginger) have been reported by Rao (1963); Muthappa (1996); Doi (1977); Khurana (1980); Rathaiah (1980); Vittal (1981); Pavgi and Upadhyay (1986); Samuels (1989); and Hyde (1997). The current study was initiated to investigate the endophytic fungal assemblages of the wild ginger, Amomum siamense Criab., at Doi Suthep-Pui National Park, Thailand. The research was primarily motivated by the desire to establish whether the endophytes in ginger differed from those in other tropical hosts. We also wanted 
to establish whether the endophytes in ginger were diverse and whether there was any evidence that the endophytes of ginger are latent pathogens.

\section{Materials and methods}

\section{Sample selection}

Ten plants of Amomum siamense were randomly collected from each of two localities in Doi Suthep-Pui National Park, Chiang Mai, Thailand. Collections were made at Huay Kok Ma $(933 \mathrm{~m}$ above sea level) and Medicinal Plant Garden $(600 \mathrm{~m}$ above sea level) in August 1999 (wet season) and February 2000 (dry season). One pseudostem, two leaves ( 1 young and 1 old), and one rhizome from each plant were randomly removed and returned to the laboratory.

\section{Surface sterilization and isolation of endophytes}

Samples were washed in running tap water for $15 \mathrm{~min}$. Five segments (10 mm long) were then cut from each pseudostem, and five rhizome segments from each plant were cut into $10-\mathrm{mm}^{3}$ cubes. Twenty discs ( $5 \mathrm{~mm}$ diam.) were cut from the leaves, using a sterile cork borer. The discs either included a vein (10 samples) or consisted of only interveinal lamina (10 samples). The surface sterilization method chosen was similar to that used for the isolation of endophytes from palms (Taylor et al. 1999), but modified based on the thickness of the ginger tissues, following pilot experiments. Samples were triple surface sterilized by soaking in $95 \%$ ethanol for $15 \mathrm{~s}$, then in a solution of sodium hypochlorite (1\%) for $5 \mathrm{~min}$., and finally in $95 \%$ ethanol for $15 \mathrm{~s}$. Samples were dried on sterilized filter paper and were then transferred to $2 \%$ malt extract agar $+0.03 \%$ Rose Bengal $+0.1 \%$ streptomycin sulphate. Labelled plates were incubated at room temperature $\left(27^{\circ} \mathrm{C}-30^{\circ} \mathrm{C}\right)$ for $1-$ 2 weeks, and hyphae growing out from the tissues were transferred to tubes containing corn meal agar.

\section{Identification}

The isolates were incubated for 4-8 weeks, and if sporulating, were identified to genus or species using taxonomic keys (Ellis 1971, 1976; Carmichael et al. 1980; Sutton 1980; Von Arx 1981; Hyde et al. 2000). Isolates that failed to sporulate within 8 weeks were subcultured on corn meal agar and potato dextrose agar, containing autoclaved strips of host leaf tissue. After two months, sterile isolates were identified as mycelia sterilia. These methods were similar to those used to promote sporulation in endophytic fungi of Bambusa tuldoides Munro and Livistona chinensis (Guo et al. 1998; Umali et al. 1999).

\section{Statistical analyses}

Isolate prevalence and intensity were calculated as follows:

$$
\begin{aligned}
& \text { Isolate prevelence }= \\
& \frac{\text { Total number of samples yielding } \geq 1 \text { isolate }}{\text { Total number of samples in that trial }} \times 100
\end{aligned}
$$

[2] Intensity =

Total number of isolates yielded in a given trial Total number of samples in that trial

Isolate prevalence is expressed as percent, as commonly used by other workers (Petrini et al. 1982). Intensity was also calculated and used to demonstrate the degree of multiple colonization from the samples in different trials, but was not expressed as a percentage. A Chi-squared $\left(\chi^{2}\right)$ goodness-of-fit test was performed to test whether the isolate prevalence for the four trials was statistically different. Nonparametric statistical tests were used because the data in most cases did not fit the assumptions for parametric statistics. A Mann-Whitney test was performed on isolates from old and young leaves and pseudostems at each site (Taylor et al. 1999). A Kruskal-Wallis rank-sum test was used for multisample analysis of the number of isolates recovered from vein and intervein tissues for all leaves at each site and for the number of isolates recovered from different tissue types at each site between wet and dry seasons (Petrini et al. 1982). In all analyses, $P$ values are described as follows: $P<0.05, P<0.01$, and $P<0.001$, for Chi-squared, Mann-Whitney, and Kruskal-Wallis, respectively.

\section{Results}

\section{Isolate prevalence and intensity}

A total of 1200 samples were processed from two sites in the wet and dry seasons, and 1222 fungal isolates were recovered. The overall isolate prevalence $(\%)$ and intensity for the assemblages of endophytes recovered at each site in wet and dry seasons are given in Table 1. There was no significant difference between isolate prevalence in each trial. In all cases, there was a rather high isolate prevalence, and overall there was a high degree of multiple infections $(22 \%-$ $38 \%$ of samples, Table 1 ).

\section{Tissue specificity}

\section{Leaf and pseudostem age analysis}

Mann-Whitney tests were performed on data at each site, and there was no significant difference between the number of isolates recovered from young and old leaves at any of the sites sampled $(P<0.05)$. However, with the exception of the dry season samples from the Medicinal Plant Garden, there were significantly more isolates recovered from old leaves, as compared with young leaves $(P=0.000)$, according to the Kruskal-Wallis rank-sum test. There was no significant difference in the number of isolates recovered from vein and intervein tissues, irrespective of leaf age.

\section{Composition of endophytic assemblages}

Of the 1222 fungal isolates recovered, 33 taxa were identified, comprising 7 Ascomycetes and 26 mitosporic fungi ( 6 Coelomycetes and 20 Hyphomycetes). Dominant genera were Colletotrichum, Glomerella, and Phomopsis. The taxa occurring at relative frequencies of $>1 \%$ at each site in different seasons are presented in Table 2. Based on conidial size and colony characteristics, the Colletotrichum isolates could be separated into three taxa. However, these all fit the broad description of Colletotrichum "gloeosporioides" (Penz.) Penz. \& Sacc. in Penz (Sutton 1980). Four species of Pyricularia, including Pyricularia costina and three new species, were isolated and distinguished by conidial shape, size, and septation. Fusarium comprised five species, which were distinguished on colonial morphology and spore size, while Glomerella and Phyllosticta each comprised two species separated on colonial morphology, spore size, and spore color. Phomopsis comprised four species, which were distinguished by colonial morphology, the presence and (or) absence of $\alpha$ - and $\beta$-conidia, and the dimensions of these conidia. These species were the dominant fungal endophytes in this study. Since it is difficult to identify these taxa to spe- 
Table 1. Isolate prevalence, intensity, multiple infection, and number of taxa of endophytes isolated from Amomum siamense at each site in the wet and dry season.

\begin{tabular}{|c|c|c|c|c|}
\hline \multirow[b]{2}{*}{ Characteristic } & \multicolumn{2}{|c|}{ Wet season } & \multicolumn{2}{|c|}{ Dry season } \\
\hline & $\begin{array}{l}\text { Huay } \\
\text { Kok Ma }\end{array}$ & $\begin{array}{l}\text { Medicinal } \\
\text { Plant Garden }\end{array}$ & $\begin{array}{l}\text { Huay } \\
\text { Kok Ma }\end{array}$ & $\begin{array}{l}\text { Medicinal } \\
\text { Plant Garden }\end{array}$ \\
\hline No. of samples & 300 & 300 & 300 & 300 \\
\hline No. of isolates recovered & 284 & 362 & 283 & 293 \\
\hline Total taxa recovered & 19 & 18 & 23 & 20 \\
\hline Taxa per plant* (means + SD) & $8 \pm 2$ & $8 \pm 1$ & $8 \pm 2$ & $7 \pm 2$ \\
\hline Taxa per plant (range) & $4-12$ & $6-11$ & $5-11$ & $6-11$ \\
\hline Isolate prevalence $(\%)$ & 73 & 83.3 & 70 & 78.7 \\
\hline No. $(\%)$ of samples yielding two species & $54(25 \%)$ & $76(30 \%)$ & $68(29 \%)$ & $51(21 \%)$ \\
\hline No. $(\%)$ of samples yielding $>$ two species & $5(2 \%)$ & $19(8 \%)$ & $5(2 \%)$ & $3(1 \%)$ \\
\hline Intensity (no. of isolates per sample) & 0.99 & 1.21 & 0.96 & 0.98 \\
\hline
\end{tabular}

*Means are not significantly different according to ANOVA $(P<0.05)$.

cies level, we have combined the data of each genus for statistical comparison.

There was a large degree of overlap in the endophyte communities at the genus level. In the wet season, eight of the taxa recorded from Huay Kok Ma also occurred at the Medicinal Plant Garden, whereas in the dry season seven taxa occurred at both sites. Six taxa recorded in the wet season also occurred in the dry season.

\section{The effect of tissue type on the composition of endophytic assemblages}

Differences in endophyte assemblages in the different tissue types (leaf tissues versus pseudostem versus rhizome) would reflect the tissue preferences of the individual dominant taxa. There was little evidence of tissue specificity exhibited by the endophytes isolated in this study. However, Talaromyces flavus (Klöcker) A.C. Stolk \& R.A. Samson and Eupenicillium crustaceum Ludwig were restricted to rhizome tissues, and Phyllosticta spp. and Pyricularia spp. were restricted to leaf tissues. Phomopsis spp. appeared to have a higher occurrence on leaf and pseudostem tissues than on the rhizomes, whereas Colletotrichum "gloeosporioides" and Glomerella spp. appeared to have a higher occurrence on pseudostem tissues than on the leaves and rhizomes, respectively. Fusarium spp., however, seemed to occur recurrently on the pseudostems and thizomes. The rare species Gaeumannomyces amomi and Leiosphaerella amomi B. Bussaban, recently described by Bussaban et al. (2001), were recovered from both the rhizomes and the leaves (Table 2).

\section{Site level patterns}

At the site level, variations in the numbers of taxa per plant were examined, and the number of isolates recovered from each site in wet and dry seasons was compared (Table 1). Both sites in the wet and dry seasons were relatively homogeneous in terms of the number of taxa recovered, with no significant difference between the means of taxa per plant at each site. The range of taxa per plant varied (Table 1). In the wet season, the three most frequent endophytes at both sites were the same, although they occurred in different proportions (Table 2). However, there were differences in the three most frequent endophytes at both sites during the dry season. The differences in the assemblages of the most fre- quent endophytes in the different seasons and sites, therefore, indicated the seasonality and site-specific nature of the endophyte assemblages.

\section{Discussion}

\section{Composition of endophytic assemblages}

As no previous studies have been reported on the endophytic fungi associated with members of the Zingiberaceae, there is no data available for comparison. Of the taxa identified here from Amomum siamense, Colletotrichum "gloeosporioides", Glomerella spp., Phomopsis spp., Fusarium spp., and xylariaceous taxa have been previously recorded as endophytes in various herbaceous and woody tree host plants (Petrini et al. 1982; Bettucci and Saravey 1993; Fisher et al. 1993, 1995; Rodrigues 1994; Menendez et al. 1995; Taylor et al. 1999; Lumyong et al. 2000). In the present study, Colletotrichum "gloeosporioides" and Glomerella spp. were the most frequent species isolated. A survey of fungal endophytes associated with Trachycarpus fortunei (Hook.) H. Wendl. (palm) also recorded Glomerella (teleomorph of Colletotrichum) as the most dominant genus (Taylor et al. 1999).

Xylariaceous taxa were a frequent isolate in this study and are commonly isolated from many hosts in tropical regions (Rodrigues and Samuels 1990; Whalley 1993; Rodrigues 1994). Xylariaceous taxa were the second most dominant species isolated from leaves of Licuala ramsayi (Mueler) Domin. in the Australian tropics (Rodrigues and Samuels 1990).

In this study, Talaromyces flavus and Eupenicillium crustaceum (teleomorphs of Penicillium sp.) were commonly isolated from rhizomes of Amomum siamense. Penicillium spp. have been commonly recovered as endophytes from leaves and roots of various hosts, such as Alnus glutinosa (L.) Gaertn., Cuscuta reflexa Roxb., Picea abies (L.) Karst., Picea marina (Mill.), and Sorbus spp. (Cappellano et al. 1987; Summerbell 1989; Valla et al. 1989; Holdenrieder and Sieber 1992; Suryanarayanan et al. 2000).

\section{Isolate prevalence and intensity}

Isolate prevalence is an indication of the number of endophytic fungi. In this study, the isolate prevalence was 
Table 2. Relative frequencies (RF) (\%) and colonization frequencies (CF) (\%) of endophytes from Amomum siamense occurring at relative frequencies of $>1 \%$.

\begin{tabular}{|c|c|c|c|c|c|c|c|c|c|c|c|}
\hline \multirow[b]{3}{*}{ Taxa } & \multicolumn{4}{|c|}{ Wet season } & \multicolumn{4}{|c|}{ Dry season } & \multirow{2}{*}{\multicolumn{2}{|c|}{ Plant part }} & \multirow[b]{3}{*}{$\begin{array}{l}\text { Rhizome } \\
\text { (CF) }\end{array}$} \\
\hline & \multicolumn{2}{|c|}{$\begin{array}{l}\text { Huay Kok } \\
\text { Ma }\end{array}$} & \multicolumn{2}{|c|}{$\begin{array}{l}\text { Medicinal } \\
\text { Plant Garden } \\
\end{array}$} & \multicolumn{2}{|c|}{$\begin{array}{l}\text { Huay Kok } \\
\text { Ma }\end{array}$} & \multicolumn{2}{|c|}{$\begin{array}{l}\text { Medicinal } \\
\text { Plant Garden } \\
\end{array}$} & & & \\
\hline & RF & $\mathrm{CF}$ & RF & $\mathrm{CF}$ & RF & $\mathrm{CF}$ & RF & $\mathrm{CF}$ & $\begin{array}{l}\text { Leaf } \\
\text { (CF) }\end{array}$ & $\begin{array}{l}\text { Pseudostem } \\
\text { (CF) }\end{array}$ & \\
\hline $\begin{array}{l}\text { Colletotrichum } \\
\text { "gloeosporioides" }\end{array}$ & 33.1 & 32.7 & 21.8 & 27 & 20.7 & 20 & 26.8 & 26.3 & 28.8 & 37.5 & 6 \\
\hline Eupenicillium crustaceum & 1.4 & 1.3 & 6.2 & 7.7 & 0 & 0 & 0 & 0 & 1 & 0 & 10.5 \\
\hline Fusarium spp. & 5.4 & 5.3 & 4.6 & 5.7 & 5.9 & 5.7 & 1.7 & 1.7 & 1.4 & 13.5 & 8.5 \\
\hline Glomerella spp. & 13.2 & 13 & 11 & 13.7 & 20.4 & 19.7 & 16.3 & 16 & 17 & 22.5 & 3 \\
\hline Phomopsis spp. & 9.8 & 9.7 & 8.3 & 10.3 & 7.6 & 7.3 & 4.7 & 4.7 & 9.5 & 9 & 0.5 \\
\hline Phyllosticta spp. & 7.1 & 7 & 4.6 & 5.7 & 0 & 0 & 0 & 0 & 4.9 & 0.5 & 1 \\
\hline $\begin{array}{l}\text { Pyricularia spp. (includ- } \\
\text { ing } P \text {. costina) }\end{array}$ & 5.1 & 5 & 4.6 & 5.7 & 3.5 & 3.3 & 8.8 & 8.7 & 8.5 & 0 & 0 \\
\hline Talaromyces flavus & 0 & 0 & 0 & 0 & 2.8 & 2.7 & 1.4 & 1.3 & 0 & 0 & 6 \\
\hline Xylariaceous taxa & 2.4 & 2.3 & 26.9 & 33.3 & 12.8 & 12.3 & 16.9 & 16.7 & 18.8 & 11 & 11 \\
\hline Mycelia sterilia & 15.9 & & 5.6 & & 9 & & 8.5 & & & & \\
\hline Rare isolates* & 6.6 & & 6.4 & & 17.3 & & 14.9 & & & & \\
\hline Total & 76.8 & & 87.4 & & 73.7 & & 76.6 & & & & \\
\hline Grand total & 100 & & 100 & & 100 & & 100 & & & & \\
\hline
\end{tabular}

*Taxa occurring at $<1 \%$ RF in different seasons at each site. Wet season-Huay Kok Ma: Gaeumannomyces amomi, Gilmaniella humicola, Humicola fuscoatra, Leiosphaerella amomi, Papulospora sp., Pestalotiopsis sp., Phoma sp., Thermomyces sp., and Trichoderma sp. Medicinal Plant Garden: Drechslera australiensis, Fusicoccum sp., Gelasinospora sp., Geniculosporium sp. 2, Humicola fuscoatra, Nigrospora oryzae, Phoma sp., and Stachybotrys sp. Dry season--Huay Kok Ma: Aspergillus niger, Cylindrocarpon sp., Cylindrocladium sp. 1, Cylindrocladium sp. 2, Eupenicillium crustaceum, Geniculosporium sp. 2, Gilmaniella humicola, Nigrospora oryzae, Penicillium sp., Pestalotiopsis sp., Phyllosticta spp., and Trichoderma sp. Medicinal Plant Garden: Cladosporium cladosporioides, Cylindrocladium sp. 1, Eupenicillium crustaceum, Gaeumannomyces amomi, Geniculosporium sp. 1, Geniculosporium sp. 2, Gilmaniella humicola, Gliomastix murorum var. polychroma, Humicola fuscoatra, Nigrospora oryzae, and Phyllosticta spp.

comparatively high in both sites in both wet and dry seasons $(70 \%-83 \%)$. The isolate prevalence by endophytes on Amomum siamense are high when compared with the isolate prevalence of endophytes in other hosts, e.g., Licuala ramsayi, Euterpe oleraceae Mart., Juncus bufonius (L.), Juncus imbricatus (L.) var. chamnissonis, and Trachycarpus fortunei, with $12.5 \%, 21 \%-30 \%, 34 \%, 45.8 \%$, and $23 \%-$ $57 \%$ isolate prevalence, respectively (Rodrigues and Samuels 1990; Rodrigues 1994; Menendez et al. 1995; Taylor et al. 1999). The climatic conditions were different, with higher humidity and rainfall in this study than in that of Taylor et al. (1999). Taylor et al. (1999) showed that the endophyte isolate prevalence in Trachycarpus fortunei declined with decreasing relative humidity and rainfall. Carroll and Carroll (1978) demonstrated that Douglas fir was more heavily infected in moist sites than in dry sites and suggested that differences in elevation, humidity, density of canopy cover, and innate host susceptibility were likely to cause the observed differences in endophyte infection among sites. Therefore, the high isolate prevalence of Amomum siamense at the two sites during the wet and dry season may result from climatic conditions, including higher humidity, temperature, and rainfall (mean relative humidity $70 \%-80 \%$, mean temperature $20^{\circ} \mathrm{C}-23^{\circ} \mathrm{C}$, mean yearly rainfall 1350 $2500 \mathrm{~mm}$ ). Amomum siamense is also a plant that occurs on the forest floor under other trees and plants. Endophyte innocula from these plants and high humidity on the forest floor may account for the high colonization rates of endophytes in Amomum siamense.

\section{Tissue specificity}

\section{Leaf and pseudostem age analysis}

The results of this study show a general increase in the number of endophytes recovered with increasing tissue age, especially from the leaf tissues. This is in agreement with data obtained for tropical palms (Rodrigues and Samuels 1990; Rodrigues 1994). Frequency of colonization and species diversity has also been found to increase with the age of organs or tissues in several hosts (Carroll et al. 1977; Petrini and Carroll 1981; Rodrigues 1994; Bernstein and Carroll 1977; Brown et al. 1998; Taylor et al. 1999; Umali et al. 1999). The factors that may contribute to change in the endophytic community with leaf age include weathering of the leaf cuticle, the presence of wounds, increased exposure to propagules with time, and changes in leaf physiology and chemistry (Petrini and Carroll 1981; Stone 1987; EpinosaGracia and Longenheim 1990). Amomum siamense occurs beneath trees, and transmission of endophyte to Amomum siamense may be from spore innocula from the trees.

\section{Vein and intervein analysis}

The results of this study indicated that there was no significant difference in the number of isolates recovered from 
vein and intervein tissues. This differs from results reported from palms (Rodrigues and Samuels 1990) and other monocotyledons (Brown et al. 1998).

\section{The role of endophytes in Amomum siamense}

The endophytes isolated from Amomum siamense included commonly isolated genera, e.g., Colletotrichum "gloeosporioides", Glomerella spp., and Phomopsis spp. (Petrini et al. 1982; Bettucci and Saravey 1993; Fisher et al. 1993, 1995; Rodrigues 1994; Menendez et al. 1995; Taylor et al. 1999), as well as taxa that had not been previously isolated as endophytes, e.g., Gaeumannomyces amomi and Leiosphaerella amomi. Endophytes in tropical plants are thought to benefit the host plant by enhancing absorption of soil nutrients, such as phosphorus, by providing protection from insect attack and by possibly inhibiting the development of plant pathogens (Thomson et al. 1986; Latch 1993; Stone et al. 2000). Endophytic fungi may develop as pathogens or saprobes (Latch 1993; Brown et al. 1998), and some of the endophytes isolated from Amomum siamense are possible latent pathogens. Colletotrichum capsici (Syd.) Butl. \& Bisby, Colletotrichum "gloeospoioides", Fusarium oxysporum Schlechtend.:Fr. f.sp. zingiberi E.E. Trujillo, Fusarium solani (Mart.) Sacc., Phomopsis sp., Phyllosticta zingiberi F. Stevens \& Ryan, and Pyricularia curcumae Y. Rathaiah are known to be pathogens of Zingiberaceae (Pavgi and Upadhyay 1986; Rathaiah 1980; Sontirat et al. 1994; Farr et al. 1995). Two species (Colletotrichum "gloeosporioides" and Phomopsis sp.) were associated with leaf disease of Amomum siamense on the plants sampled in this study.

This study has shown that zingiberaceous species contain similar endophytic fungal communities as those of other monocotyledons (Rodrigues 1994; Menendez et al. 1995; Taylor et al. 1999). This is interesting because it places doubt on the well-used phrase that endophytes are beneficial to the host. It is not clear that any of the fungi isolated here as endophytes may benefit the host, and certainly further work should be conducted on this aspect. Of the fungi isolated, Gaeumannomyces amomi, Leiosphaerella amomi, and Pyricularia spp. are probably unique to the Zingiberaceae, and their role also needs investigation. Although the fungi isolated in this study are not generally unique to Zingiberaceae, it is believed that they may be an excellent source of new compounds (Dreyfuss and Petrini 1984; Hyde 2000).

\section{Acknowledgements}

Funds for this research were provided by The Thailand Research Fund (Golden Jubilee Ph.D. Program) and Biodiversity and Training Program (BRT 142006), Thailand. W. Photita and W. Techa are thanked for help with collecting samples.

\section{References}

Bernstein, M.E., and Carroll, G.C. 1977. Internal fungi in old growth Douglas fir foliage. Can. J. Bot. 55: 644-653.

Bettucci, L., and Saravey, M. 1993. Endophytic fungi of Eucalyptus globulus: a preliminary study. Mycol. Res. 97: 679-682.
Brown, K.B., Hyde, K.D., and Guest, D.I. 1998. Preliminary studies on endophytic fungal communities of Musa acuminata species complex in Hong Kong and Australia. Fungal Div. 1: 27-51.

Bussaban, B., Lumyong, S., Lumyong, P., McKenzie, E.H.C., and Hyde, K.D. 2001. Two new species of endophytes (Ascomycetes) from Zingiberaceae sporulating in culture. Nova Hedwigia, 72: (In press).

Cappellano, A., de Quartre, B., Valla, G., and Moiroudo, A. 1987. Root nodule formation by Penicillium sp. on Alnus glutinosa and Alnus incana. Plant Soil, 104: 45-51.

Carmichael, J.W., Kendrick, W.B., Conners, I.L., and Sigler, L. 1980. Genera of Hyphomycetes. The University of Alberta Press, Edmonton, Alberta, Canada.

Carroll, G.C., and Carroll, F.E. 1978. Studies on the incidence of coniferous needle endophytes in the Pacific Northwest. Can. J. Bot. 56: 3034-3043.

Carroll, F.E., Müller, E., and Sutton, B.C. 1977. Preliminary studies on the incidence of needle endophytes in some European conifers. Sydowia, 29: 87-103.

Clay, K. 1986. Grass endophytes. In Microbiology of the phyllosphere. Edited by N.J. Fokkema and J. van den Heuvel. Cambridge University Press, Cambridge, U.K. pp. 188-204.

Dahlman, D.L., Eichenseer, H., and Siegel, M.R. 1991. Chemical perspective on endophyte grass interactions and their implications to insect herbivory. In Microbial mediation of plant-herbivore interaction. Edited by P. Barbosa, V.A. Krischik, and C.G. Jones. John Wiley and Sons, New York. pp. 227-252.

Doi, Y. 1977. Protocreopsis, a new genus of the Hypocreales. Kew Bull. 31: $511-555$.

Dreyfuss, M.M., and Petrini, O. 1984. Further investigations on the occurrence and distribution of endophytic fungi in tropical plants. Bot. Hely. 94: 33-40.

Ellis, M.B. 1971. Dematiaceous Hyphomycetes. Commonwealth Mycological Institute, Kew, England.

Ellis, M.B. 1976. More dematiaceous Hyphomycetes. Commonwealth Mycological Institute, Kew, England.

Epinosa-Gracia, F.J., and Longenheim, J.H. 1990. The leaf fungal endophytic community of a coastal red wood population-diversity and spatial patterns. New Phytol. 116: 89-98.

Farr, F.D., Bills, G.F., Chamuris, G.P., and Rossman, A.Y. 1995. Fungi on plant and plant products in the United States. The American Phytopathological Society, St. Paul, Minn., U.S.A.

Fisher, P.J., Petrini, O., and Sutton, B.C. 1993. A comparative study of fungal endophytes in leaves, xylem and bark of Eucalyptus in Australia and England. Sydowia, 45: 338-345.

Fisher, P.J., Petrini, L.E., Sutton, B.C., and Petrini, O. 1995. A study of fungal endophytes in leaves, stem and roots of Gynoxis oleifolia Muchler (Compositae) from Ecuador. Nova Hedwigia, 60: $589-594$.

Fröhlich, J., Hyde, K.D., and Petrini, O. 2000. Endophytic fungi associated with palms. Mycol. Res. 104: 1202-1212.

Guo, L.D., Hyde, K.D., and Liew, E.C.Y. 1998. A method to promote sporulation in palm endophytic fungi. Fungal Div. 1: 109-113.

Holdenrieder, O., and Sieber, T.N. 1992. Fungal associations of serially washed healthy non-mycorrhzal roots. Mycol. Res. 96: 151-156.

Hyde, K.D. 1997. Additions to the genus Linocarpon (Ascomycetes: Hyponectriaceae). Bot. J. Linn. Soc. 123: 109-131.

Hyde, K.D. 2000. Improving screening in filamentous fungi. In Bio-exploitation of fungi. Edited by S.B. Pointing and K.D. Hyde. Fungal Diversity Press, Hong Kong.

Hyde, K.D., Taylor, J.E., and Fröhlich, J. 2000. Genera of Ascomycetes from palm. Fungal Diversity Press, Hong Kong. 
Khurana, I.P.S. 1980. The Clavariaceae of India. XIV. The genus Typhula. Mycologia, 72: 708-727.

Latch, G.C.M. 1993. Physiological interactions of endophytic fungi and their hosts; biotic stress tolerance imparted to grasses by endophytes. Agric. Ecosyst. Environ. 44: 143-156.

Lumyong, S., Thongantha, S., Lumyong, P., and Tomita, F. 2000. Endophytic fungi from 13 bamboo species in Thailand. Biotechnol. Sustainable. Util. Biol. Resourc. Trop. 14: 96-101.

Menendez, A., Bertoni, M.D., and Cabral, D. 1995. Comparative study of occurrence of fungal endophytes in Juncus species of Argentina. Nova Hedwigia, 60: 583-588.

Muthappa, B.N. 1996. A new species of Sphaceloma on cardamom from India. Sydowia, 19: 143-145.

Pavgi, M.S., and Upadhyay, R. 1986. Some parasitic fungi on turmeric from India. Sydowia, 21: 100-104.

Petrini, O., and Carroll, G.C. 1981. Endophytic fungi in foliage of some Cupressaceae in Oregon. Can. J. Bot. 59: 629-636.

Petrini, O., Stone, J., and Carroll, F.E. 1982. Endophytic fungi in evergreen shrubs in western Oregon: a preliminary study. Can. J. Bot. 60: 789-796.

Rao, V.G. 1963. Some new records of fungi-imperfecti from India. Sydowia, 16: 41-45.

Rathaiah, Y. 1980. Leaf spot of turmeric. Plant Dis. 64: 104-105.

Rodrigues, K.F. 1994. The foliar fungal endophytes of the Amazon palm Euterpe oleraceae. Mycologia, 86: 376-385.

Rodrigues, K.F., and Samuels, G.J. 1990. Preliminary study of endophytic fungi in a tropical palm. Mycol. Res. 94: 827-830.

Samuels, G.J. 1989. Nectria and Sesquillium. Mem. N.Y. Bot. Gard. 49: 266-285.

Sontirat, P., Pitakprivan, P., Khamhangridtirong, T., Choobamroong, W., and Kueprakone, U. 1994. Host index of plant diseases in Thailand. Mycology Section, Plant Pathology and Microbiology Division, Department of Agriculture, Bangkok, Thailand.

Stone, J.K. 1987. Initiation and development of latent infections by Rhabdocline pakeri on Douglas fir. Can. J. Bot. 65: 2614-2621.
Stone, J.K., Bacon, C.W., and White, J.F., Jr. 2000. An overview of endophytic microbes: endophytism defined. In Microbial endophytes. Edited by C.W. Bacon and J.F. White, Jr. Marcel Dekker, New York. pp. 1-29.

Summerbell, R.C. 1989. Microfungi associated with the mycorrhizal mantle and adjacent microhabitats within the rhizosphere of black spruce. Can. J. Bot. 67: 1085-1095.

Suryanarayanan, T.S., Senthilarasu, G., and Muruganandam, V. 2000. Enophytic fungi from Cuscuta reflexa and its host plants. Fungal Div. 4: 117-123.

Sutton, B.C. 1980. The Coelomycetes. Commonwealth Mycological Institute, Kew, U.K.

Taylor, J.E., Hyde, K.D., and Jones, E.B.G. 1999. Endophytic fungi associated with the temperate palm Trachycarpus fortunei both within and outside of its natural geographic range. New Phytol. 142: 335-346.

Thomson, B.D., Robson, A.D., and Abbott, L.K. 1986. Effects of phosphorus and the formation of mycorrhizas by Gigaspora calospora and Glomus fasciculatum in relation to root carbohydrates. New Phytol. 103: 751-765.

Umali, T.E., Quimio, T.H., and Hyde, K.D. 1999. Endophytic fungi in leaves of Bambusa tuldoides. Fung. Sci. 14: 11-18.

Valla, G., Cappellano. A., Hugueney, R., and Moiroudo, A. 1989. Penicillium nodositatum Valla, a new species including myconodules on Alnus roots. Plant Soil, 114: 142-146.

Vittal, B.P.R. 1981. Xenosporium intermedium sp. nov., from India. Trans. Br. Mycol. Soc. 76: 513-515.

Von Arx, J.A. 1981. The genera of fungi sporulating in pure culture. A.R. Gantner, Verlag Kommanditgesellschaft, Germany.

Whalley, A.J.S. 1993. Tropical Xylariaceae: their distribution and ecological characteristics. In Aspects of tropical mycology. S. Isacc, J.C. Frankland, R. Watling, and A.J.S. Whalley. Cambridge University Press, Cambridge, U.K. pp. 109-119. 